\title{
Factors Affecting Reading Comprehension among Malaysian ESL Elementary Learners
}

\author{
Stephanie Kiew, Parilah M. Shah* \\ Universiti Kebangsaan Malaysia, Bangi, Malaysia \\ Email: tiffany090115@gmail.com, ^drparila@gmail.com
}

How to cite this paper: Kiew, S., \& Shah, P. M. (2020). Factors Affecting Reading Comprehension among Malaysian ESL Elementary Learners. Creative Education, 11, 26392659.

https://doi.org/10.4236/ce.2020.1112196

Received: October 28, 2020

Accepted: December 14, 2020

Published: December 17, 2020

Copyright $\odot 2020$ by author(s) and Scientific Research Publishing Inc. This work is licensed under the Creative Commons Attribution International License (CC BY 4.0).

http://creativecommons.org/licenses/by/4.0/ (c) (i) Open Access

\begin{abstract}
This study explored Level 2 primary school English as a Second Language (ESL) learners' reading comprehension skill of a sub-urban school in Mukah, Sarawak. The objectives of this study were to identify the factors that contributed to learners' comprehension skill, and to compare these factors in term of gender. The respondents comprised of 50 males and 50 females aged between 10 to 12 years old from major ethnics in Mukah namely, Melanau, Iban, Malay and Chinese. A set of questionnaire that consisted of 16 questions were administered via Google Form. The findings suggested that motivation and interest, prior knowledge and vocabulary knowledge influenced learners' reading comprehension skill. In addition, there was no significant relationship between genders and these factors. The findings from this research were important to determine reading strategies based on the factors listed to help the poor readers.
\end{abstract}

\section{Keywords}

Reading Comprehension, Motivation and Interest, Prior Knowledge, Vocabulary Knowledge, Gender

\section{Introduction}

English language is being used as the mean of communication or known as "lingua-franca" worldwide. According to World Population Review (2019), English has gained traction across the globe during the $17^{\text {th }}$ century due to domination of British Empire and the United States, in which making English as the leading language of international discourse. Reddy \& Mahavidyalaya (2016) estimated that there are approximately 375 million first language speaker of English and 750 million speak English as a second language in the world. David (2003) in her study denoted that less than one out of every four users of English around 
the world is the native speaker of the language. Consequently, most interactions in English language happen in intercultural contexts, between native and the non-native speakers, which bring impact to achieve cultural and linguistic integration among the English users. The significance of English is clearly evidenced in many domains, ranging from trades to international politics to academia, and the globalization fostered by the advancement of internet and ICT, which has accentuated this development. Henceforth, in order to meet the demands of evolving globalization era, English language proficiency is crucial to be acquired as it is the medium of knowledge dissemination.

As the integral part of language acquisition, reading skill is one of the pinnacles of language that would bring impact on one's language development through the acquisition of vocabulary and sentence structures from the reading text. Alfassi (2004) emphasized that reading is a vital skill in language learning and acquisition, which involve complex cognitive activity that involves the integration of memory and meaning construction, in order to adequately function and obtain information in the society. Walker (2001) further elaborated that reading comprises of a series of process whereby the readers shift between sources of information, elaborate meaning and strategies, evaluating their understanding and the application of social context to reflect their response. Krashen \& Brown (2007) agreed that reading is the most fundamental skill among the four skills of language learning and acquisition as it is able to improve the overall language proficiency. Furthermore, Sadiku (2015) highlighted that reading skill is a tool for achieving an effective written communication. Most importantly, the ability to master reading comprehension skill is critical for successful academic performance among the learners (Bernhadt, 2011).

In Malaysian education context, a child has been taught and exposed to the English language as early as preschool, at the tender age of 5 - 6 years old then continues to be taught as a compulsory subject in primary level and secondary level of schooling. The significant of English language learning has been emphasized in the education system to meet the demands of evolving needs in Science and Technology (ICT) and the Fourth Industry Revolution, which require the Malaysian students to be proficient in the language in order to compete globally. This is portrayed in Malaysian Education Reformation in Malaysian Education Blueprint (2013-2025) Shift 2, which putting emphasis on the needs of the students to be at least a bilingual, whom can communicate in both Malay language and English language. The inclusion of English language as a compulsory subject is an effort to expose the pupils in their learning of the language. English language learning consists of listening and speaking skills, reading skill, writing skill as well as grammar components. In Malaysian primary classroom context, modular approach is used to teach these skills, whereby each skill is focused in each lesson Apart from that, NILAM program is carried out to enhance the reading skill and to inculcate the reading interest among the primary school pupils. Thus, at the end of the 6-year of primary schooling, the pupils are expected to be 
able to read in English language as well as Malay language.

Reading skill demands the learners not only to pronounce the words correctly, but also to comprehend the meaning of the diction used or semantic structures of the English language. This is supported by Chang et al. (2018) agreed that reading comprehension is an active cognitive process that require an individual to interact with the reading materials. Phantharakphong \& Pothita (2014) further elaborated that the learners are having difficulties to understand the written text as they are yet to master the reading comprehension first. Hence, due to the complex nature of the language, which comprises of vocabulary, grammar and lexical form, reading comprehension is difficult to be acquired by the young learners in primary school pupils, even though they have been taught on reading skill since their early education stage. This is in accordance to New Straits Time (2016) as in Kamarundzaman (2014), MOE reported that 162,000 learners from primary and secondary schools in Malaysia were illiterate. Among the bulk of 162,000 illiterate learners, 120,000 of them were in primary schools. Furthermore, a research by Fong (2012) revealed that overall English literacy among the learners in Malaysia was only 27.2\%. In addition, Hayes (2014) in his assessment of English provision in primary schools, found that policy decisions to lower the starting age in learning the English language deem to be unsuccessful. These statistics are at alarming rate to our education system because despite of the inclusion of English as a compulsory subject since Year 1, the pupils are still struggling to achieve the mastery level in reading skill. Mokotsi (2005), Mansor (2017) expressed that governments, teachers and shareholders in education sector share a genuine concern in promoting reading habits as this skill is a necessity in education.

Hence, reading comprehension difficulty among ESL learners has been a focus since the beginning of 1960s (Vellutino et al., 2004). This is because comprehension of language does not merely involve the understanding at words level, but the ability to engage actively with the content to form a mental representation (Rashid, 2012). Wolf \& Bowers (1999) associated poor reading comprehension skill with reading disability components such as selective phonological deficits, selective rapid automatized naming (RAN) deficits and combined deficits. Less time spent on reading, which later leads to limited vocabulary range and general knowledge are the factors that contribute to reading comprehension disability (Yunus, Mohamad, \& Waelateh, 2016). Numerous studies had been done on reading strategies to develop language learners' reading comprehension skill (Zare \& Nooreen, 2011). Nevertheless, it is important to examine the factors that contribute to poor reading comprehension at primary level in order to effectively implement the suggested strategies (Iqbal et al., 2015).

Thus, this paper aims to explore the factors affecting reading comprehension among the ESL Level 2 primary school learners. Besides that, this study concerns with examining the gender differences in reading comprehension related to the identified factors. 


\section{Literature Review}

\subsection{Review of Literature}

This chapter reviews the related literature for the proposed study of the exploring the impact of variables namely reading interest and motivation, prior knowledge as well as range of vocabulary knowledge on learners' reading comprehension ability.

In defining reading concept, the emphasis will be on reading English among the ESL learners. In the learning English as a Second Language, it is vital to compare that the reading proficiency in the second language (L2) is affected by the learners' first language (L1) reading proficiency. Hellekjaer (2009) proposed that if the learners' proficiency level in L1 falls far below a certain level, then it would impede the transfer of reading skill and strategies of the L2 (p. 200). The transferred of a good L1 reading ability canto L2 is only possible after the learners have acquired a minimum level of L2 (Byram, 2011). Jun \& Wu (2009) viewed reading as a passive process whereby the readers decode the written words without the application of their own knowledge to interact with the text. Tamrackitkun traced that the earliest definition was by Huey (1908) who signified that reading is a process to obtain information from the printed materials in which the mind takes notes of the printed words. A similar definition was proposed by Walcutt (1967) who claimed that reading is the ability to decode symbols and understand the text, however, he added engagement with printed material and reading motivation to the context (Golden \& Wilson, 2015). Denton \& Otoiba (2011) further explained that the process of reading involves phonological awareness, in which the readers become aware of sounds and grouping of sounds.

On the other hand, some researchers argued that reading cannot occur without comprehension. Randi, Newman, \& Grigorenko (2010) explained that reading encompasses of decoding and comprehension. Eun (2015) agreed that the reader would fail to comprehend the text if he or she is lacking in one of the components. Moreover, Pearson \& Anderson (1985) asserted that reading without comprehension is not reading. This is supported by Panigrahi (2010), who stated that reading includes the process of making meaning of the text. Similarly, Grabe \& Stroller (2002), who affirmed that reading is the ability to construct meaning from the printed materials and interpret the information appropriately. Additionally, Pollard et al. (2014) accentuated that reading is not merely decoding of letters but drawing meanings from text.

One of the major objectives of reading is to comprehend the text. The purpose may differ among different types of reading. The different types of reading are "scanning, skimming, reading to learn, reading for general knowledge, reading for critical evaluation, and reading to integrate information" (Carrell \& Eisterhold, 2012). Koda (2007) stated that reading comprehension occurs when the readers are able to link the new information that has been extracted from the reading text with their background knowledge. Reading comprehension is 
a complex process that integrated many other mental processes (Cain et al., 2004). Palinscar and Brown (1984) listed several factors that influenced reading comprehension. These factors are related to the text, context, tasks, and the readers.

Reading comprehension consists of two crucial components namely language comprehension and decoding (Shankweiler et al., 1999). However, Pasquarella (2009) refererred to decoding as a low-level skill which only requires the knowledge of spelling sound to recognize and process written words. Henceforth, decoding is not sufficient to explain the process of reading because comprehension is the central part of reading. Reading comprehension is an active cognitive activity in drawing meaning through engagement with the reading text. Kruger (2008) identified reading comprehension as a process when the readers interact and make meaning of the reading text. Therefore, decoding and comprehension are intertwined and would eventually influence to reading comprehension.

The role of learners' affect that comprises of motivation and interest to read are significantly recognized in the study of reading comprehension skill. Guthrie, Coddington, \& Wigfield (2009) emphasized on the importance of reading motivation to foster a life-long reader. Even though educators recognized the significance of motivation in enhancing learners' comprehension skill, it has often been neglected in research, theory, practice and teacher education (Guthrie, Coddington, \& Wigfield, 2009). Solheim (2011) affirmed that there is a strong relationship between motivation to read and the progress of reading comprehension. In addition, motivation and interest to read are correlated to time spent on reading. Guthrie \& Wingfield (2000) explained that motivation encompasses the engagement model of reading development, which proposed that one way to improve reading comprehension is to be engaged with the reading text.

Apart from that, vocabulary knowledge is one of the determiners that determine the reading comprehension level among the ESL learners. Numerous researches suggested different amount of vocabulary to facilitate reading comprehension. Laufer (1989) proposed that a reading text must consists $95 \%$ of familiar vocabulary to be fully understood by the readers. On the contrary, Nation (2011) suggested there must be at least $98 \%$ of familiar vocabulary in a reading text. These researches indicated that the range of vocabulary is crucial to determine the learners' reading comprehension ability. If the learners have a limited range of vocabulary, normally they belong to the group of poor readers.

Last, but not least, prior knowledge also aids in reading comprehension. Floyd \& Carrell (1987) portrayed that the learners who are lacking in cultural knowledge on the target language can improve their reading comprehension ability through the teaching of the cultural knowledge of the target language. Carrell \& Wise (1998) supported that learners are able to perform better in reading comprehension if they have ample and strong prior knowledge related to the reading contents. 


\subsection{Related Studies}

A research by Ahmadi \& Pourhossein (2012) discussed on the positive impact of reading strategies to help learners in understanding main idea of a paragraph, explaining unfamiliar words, and abridge their reading. These strategies enable the learners to solve their difficulties while reading a text. There are some studies associated to the development of reading comprehension that encourage teachers to give considerable guidance to the ESL learners.

A study by Scott (2010) focused on the impact of vocabulary knowledge on learners' progress in reading comprehension. This study explored on the application of vocabulary knowledge used in reading contexts and strategies employed to guess and identified the meaning of the words. The findings obtained from the study indicated that reading comprehension was significantly affected by the range of learners' vocabulary knowledge in term of spelling and capability to decipher printed words. Recognizing words involve the process of identifying the form and understanding the meaning of words. The aim of instruction in a reading, spelling and vocabulary was to help learners to enhance their word awareness and become independent word-solvers in all areas.

The above finding was supported by Paynter, Bodrova, \& Doty (2009), who emphasized on the significance of word knowledge or vocabulary for the readers to understand the reading materials written in second language. They perceived that reading comprehension is a complex subject that comprises of several levels of processing. The potential to deal with new vocabulary or unknown words in a reading text is one of the most crucial features of reading comprehension. The readers who have a wide range of vocabulary knowledge at word level activities may progressively work towards a deeper level of text analysis.

Stanovich (1986) explored the relationship between reading deficiency and vocabulary skills. He found that children who have low reading proficiency have insufficient vocabulary range to deal with a more complex reading material. The struggling children in reading tend to read less than their peers who are more competent in reading, hence, acquire fewer new words. The limitation in their vocabulary range hinders advancement in reading comprehension skill. This would make learning more difficult and widened the gap between the skilled and less skilled learners.

Torgeson (2006) emphasized on cognitive and assertive aspects which related to memory and motivation that influenced reading comprehension. The results of this study conveyed that memory and motivation play a significant role in enhancing reading comprehension. Therefore, learners with short memory difficulties face a critical problem to understand a reading text.

Kintsch \& Kintsch (2005) regarded that working memory span or prior knowledge affected the understanding of a text. Human memory, which provides clue or context based on what they have learned or experienced before, is an important cognitive factor as it aids to learners' comprehension of the text by connecting their prior knowledge to the reading text. 
Furthermore, a study carried out by Vazalwar (2011) highlighted on the negative impacts of anxiety on the development of reading comprehension skill. The findings of the study inferred that the normal level of anxiety impacted positively on reading comprehension, whereas, an extreme level of anxiety negatively affected the learners' progress in reading comprehension. The higher anxiety among girls yielded a low performance in reading comprehension, and low anxiety level among boys produced a better result in reading comprehension.

Moreover, prior knowledge holds a significant role in facilitating reading comprehension among the young learners (Vacca \& Vacca, 2008). This is supported by Nguyen (2007) in his research which showed that learners who have prior knowledge related to the reading text could easily comprehend the text. Nevertheless, exposure to different unknown reading materials was challenging as the learners had to read a few times to understand the text.

\section{Methodology}

This study employed a quantitative research design, comprised of the efforts to determine the factors affecting ESL students reading comprehension and examine relationship between variables tested between genders. A set of questionnaire adapted from Liu, Maarof, \& Yunus, (2016), which consisted of 16 items was administered randomly on 100 respondents aged between 10 to 12 years old. The questionnaire employed 5-point Likert Scale from "Strongly Agree" to "Strongly Disagree." The respondents were equivalent in numbers, 50 males and 50 females. These questionnaires determined the factors affecting ESL leaners' reading comprehension. After that, the items were analysed descriptively to observe the significant difference between genders with respect to the factors affecting the reading comprehension.

\subsection{Population and Sample}

In this research, the target population was Level 2 pupils in Sekolah Kebangsaan (national schools), aged between 10 to 12-year-old in Malaysia. Based on the data taken from Malaysia Educational Statistics (2018), the enrollment of level 2 pupils was approximately 1.3 million across the country. However, due to the big size of the population, there was not available data for almost all individuals in a population (Hanlon \& Larget, 2011). Therefore, the scope was narrowed down to accessible population, which was all Level 2 pupils from three National School, aged between 10 to 12 years old in Mukah, Sarawak. This was because the researcher could apply the conclusion of the study on the accessible population (Hassan, 2004). Hence, in order to draw a conclusion for the entire population, the sample for this research was drawn from the accessible population in national schools in Mukah district.

In this research, convenience sampling was used as sampling method to select the respondents. In regard to answer the research questions, the sample were selected among a total of 100 Level 2 primary school pupils in Mukah, Sarawak. 
The sample was chosen as such because of its reachability and time-effectiveness as the researcher was teaching in the area, which enabled the data collection to be done efficiently in accordance to the time constraints. As the second research question aimed to observe the significant difference of factors affecting reading comprehension between genders, an equivalent number of male and female respondents were chosen to participate in the study.

\subsection{Research Instrument}

In term of items validation, the expert's opinions were counted in. Based on the selected items, a first version of the questionnaire was developed and tested on the practitioners. The reading factors questionnaire was validated by two experts (Liu, Maarof, \& Yunus, 2016). After the practitioners read and answered the items in the questionnaire, their thoughts and ideas of the items were recorded and analyzed to be improved. A pilot test of the instrument was carried out with the assistance of the school personnel in SMK Green Road, Kuching in order to statistically assess the reliability and validity of the instrument. In this study, the questionnaire was administered via Google Form due to constraints faced during Movement Control Order (MCO) during the outbreak of Covid-19 pandemic.

\subsection{Data Collection Procedure}

The first step in data collection procedure was to ask for permission to collect the data pertaining the research. The permission could be required from three levels: individuals who were in charge of the organisation, from people providing the data and campus-based institutional review boards (Creswell, 2015). In this research, the researcher sought for permission to collect data from the District Education Office, the school administrators, and the level 2 primary school pupils from three national schools in Mukah, Sarawak. A consent letter was sent to the parents to keep them informed of the participation of their children in this study.

Next, the researcher would have to consider the types of information to be collected in the research. Creswell (2015) emphasized that the researcher should examine and weigh each option so the best sources could be determined to answer research questions and to test research hypothesis. For example, in this research, a survey was employed via Google Form in order to identify variables that affect Level 2 pupils' reading comprehension in Mukah, Sarawak. Google Form was chosen as a platform because it was accessible to all the pupils since the Standard Operational Procedures (SOP), such "social distancing" and "limit physical contact" during the MCO needed to be adhered.

\subsection{Data Analysis Procedure}

The first research question was answered based on frequencies of the respondents answering each variable that affecting reading comprehension. Since the 
second research question aimed to compare the factors affecting read reading comprehension skill between male and female, Independent Samples T-test was carried out to determine the significant differences of these two groups via the IBM SPSS Statistics Version 23 application. Mann Whitney U Test was administered to determine the correlation between the variables (motivation, prior knowledge, and vocabulary) and genders.

\section{Results and Discussion}

\subsection{Results}

RQ1: What are the factors affecting ESL learners reading comprehension?

Pertaining to the first research question, the raw data obtained from the questionnaire were analysed descriptively so as to produce data that could be presented in a table and graph. The frequencies for each factor affecting ESL learners reading comprehension were calculated and presented as followed:

From Table 1, the main key factor that impeded reading comprehension skill among ESL primary school learners was vocabulary. Based on the raw data obtained, there were 56 (56\%) level 2 primary school learners agreed that low mastery of vocabulary or limited vocabulary range greatly affected their comprehension when reading a text. From the questionnaire, the participants agreed that they had to refer to the dictionary frequently to find the meaning of the words in a reading text. Besides that, there were 23 learners or equivalent to $23 \%$ of the participants voted that inability to connect prior knowledge to the reading text hindered their reading comprehension. This was evidenced on item 1 , section $c$ (previous knowledge) whereby most of the respondents answered that they could not relate previous knowledge from various sources to the reading passage. The least voted factor that affecting reading comprehension among primary school ESL learners was interest and motivation. There were only 21 out of 100 participants agreed that lack of interest and reading motivation to read English reading materials slowed down their reading comprehension in reading a text in English language. Less than $50 \%$ of the respondents were interested to read since they were young.

RQ2: Is there a significant difference between males and females with respect to the factors affecting the reading comprehension?

The second research question was answered to investigate the relationship between the variables that affecting reading comprehension and genders of the learners. Mann Whitney $U$ Test was carried out to determine the differences of these two groups via the IBM SPSS Statistics Version 23 application. The result obtained was tabulated in the table below:

Table 2 summarized the results obtained of Mann Whitney U Test on interest and motivation to read of the survey. The results showed that most of the learners made reading as their hobby and they read daily. However, it was observed that more female learners made reading as their daily activity compared to male learners. For instance, item MI_2 scored a higher mean rank for female learners 
$(M R=61.59)$, compared to male learners $(M R=39.41)$. Similarly, more female learners spent at least two hours per day to read $(\mathrm{MR}=56.23)$ as compared to male learners $(M R=44.77)$. From this, it could be deduced that female learners had the habit of reading books every day and spent at least two hours of their time to read compared to male learners. However, male learners regarded reading motivation as the drive to read more books with the $\mathrm{MR}=51.14$ as collated to female learners $(\mathrm{MR}=49.86)$. There was just a slight different between male and female learners in term of "interest to read since they were young" with MR $=51.59$ and $\mathrm{MR}=49.41$ respectively. Axiomatically, all items from MI_1 to MI_5 indicated no significant difference between male and female learners $(p>$ 0.05). Therefore, there was no significant difference between male and female learners with respect with their motivation and interest to read.

Table 1. Table of variables that affecting reading comprehension among ESL primary school learners in mukah, sarawak.

\begin{tabular}{ccc}
\hline Variable & Frequency & Percentage \\
\hline Interest and Motivation & 21 & $21 \%$ \\
Prior Knowledge & 23 & $23 \%$ \\
Vocabulary & 56 & $56 \%$ \\
\hline
\end{tabular}

Table 2. Mann whitney $U$ test on motivation and interest to read between genders.

\begin{tabular}{|c|c|c|c|c|}
\hline & Gender & $\mathbf{N}$ & Mean Rank & Sum of Ranks \\
\hline & Male & 50 & 47.28 & 2364.00 \\
\hline \multirow[t]{3}{*}{ Reading as a hobby (MI_1) } & Female & 50 & 53.72 & 26.8600 \\
\hline & Total & 100 & & \\
\hline & Male & 50 & 39.41 & 1970.50 \\
\hline \multirow[t]{3}{*}{ Read daily (MI_2) } & Female & 50 & 61.59 & 3079.50 \\
\hline & Total & 100 & & \\
\hline & Male & 50 & 51.59 & 2579.50 \\
\hline \multirow{3}{*}{$\begin{array}{c}\text { Interested in reading since } \\
\text { young (MI_3) }\end{array}$} & Female & 50 & 49.41 & 2470.50 \\
\hline & Total & 100 & & \\
\hline & Male & 50 & 51.14 & 2557.00 \\
\hline \multirow[t]{3}{*}{$\begin{array}{l}\text { Interest motivates to read } \\
\text { more books (MI_4) }\end{array}$} & Female & 50 & 49.86 & 2493.00 \\
\hline & Total & 100 & & \\
\hline & Male & 50 & 44.77 & 2238.50 \\
\hline \multirow[t]{2}{*}{$\begin{array}{l}\text { Reading at least two hours } \\
\text { daily (MI_5) }\end{array}$} & Female & 50 & 56.23 & 2811.50 \\
\hline & Total & 100 & & \\
\hline
\end{tabular}


Besides that, prior knowledge was determined as one of the key factors that affecting ESL learners' reading comprehension skill. The raw data from the questionnaire was analyzed and Mann Whitney $U$ test was carried out to determine the correlation between prior knowledge and reading comprehension. The result was as followed:

Table 3 showed the result of Mann Whitney U test for prior knowledge domain. The results indicated that there was a noticeable difference between male learners and female learners in term of combining new information with what had been read in order to grasp a better understanding of the reading text. Female learners, outperformed the male learners with $\mathrm{MR}=57.26$ compared to $\mathrm{MR}=43.74$ as scored by male learners. In addition, the findings also revealed that female learners had the ability to apply what they had learnt and read to facilitate their reading with $\mathrm{MR}=54.11$ compared to male learners $(\mathrm{MR}=46.89)$. Besides that, similar pattern was observed in connecting prior knowledge from various sources to the passage, whereby female learners scored a higher mean rank, $(M R=54.87)$ compared to male leaners $(M R=46.13)$. Meanwhile, in term of relating new information to the background knowledge, female learners performed better $(M R=54.80)$ compared to male learners $(M R=46.20)$. Apart from that, female learners were able to use their prior knowledge to make prediction of the main idea in the reading text as compared to male learners, with

Table 3. Mann whitney $\mathrm{U}$ test on prior knowledge between genders.

\begin{tabular}{|c|c|c|c|c|}
\hline & Gender & $\mathbf{N}$ & Mean Rank & Sum of Ranks \\
\hline \multirow{3}{*}{$\begin{array}{l}\text { Connect previous knowledge from } \\
\text { different sources to the passage } \\
\qquad \text { (PK_1) }\end{array}$} & Male & 50 & 46.13 & 2306.50 \\
\hline & Female & 50 & 54.87 & 2743.50 \\
\hline & Total & 100 & & \\
\hline \multirow{3}{*}{$\begin{array}{l}\text { Relate new information to the } \\
\text { background knowledge to assist } \\
\text { understanding of the text (PK_2) }\end{array}$} & Male & 50 & 46.20 & 2310.00 \\
\hline & Female & 50 & 54.80 & 2740.00 \\
\hline & Total & 100 & & \\
\hline \multirow{3}{*}{$\begin{array}{l}\text { Imagine some scenes describe in } \\
\text { the passage to facilitate reading } \\
\text { comprehension (PK_3) }\end{array}$} & Male & 50 & 51.19 & 2559.50 \\
\hline & Female & 50 & 49.81 & 2490.50 \\
\hline & Total & 100 & & \\
\hline \multirow{3}{*}{$\begin{array}{l}\text { Use Previous Knowledge and } \\
\text { common sense to predict the main } \\
\text { idea of the passage (PK_4) }\end{array}$} & Male & 50 & 49.34 & 2467.00 \\
\hline & Female & 50 & 51.66 & 2583.00 \\
\hline & Total & 100 & & \\
\hline \multirow{3}{*}{$\begin{array}{l}\text { Combine new information with } \\
\text { what have been read to understand } \\
\text { better (PK_5) }\end{array}$} & Male & 50 & 43.74 & 2187.00 \\
\hline & Female & 50 & 57.26 & 2863.00 \\
\hline & Total & 100 & & \\
\hline \multirow{3}{*}{$\begin{array}{l}\text { Apply what have been learnt } \\
\text { and read to facilitate reading } \\
\text { comprehension (PK_6) }\end{array}$} & Male & 50 & 46.89 & 2344.50 \\
\hline & Female & 50 & 54.11 & 2705.50 \\
\hline & Total & 100 & & \\
\hline
\end{tabular}


$M R=51.66$ and 49.34. From the results, it could be conclude that female learners were able to apply and use their prior knowledge into practice to enhance their reading comprehension skill during reading activities. However, male learners scored slightly higher for the ability to imagine some scenes described in the passage with $\mathrm{MR}=51.19$ compared to female learners 49.81 . This showed that male learners had the ability to form mental image of the contexts and visualize the scenes as descried in the text while reading.

Last but not least, vocabulary knowledge was also a variable that affected learners' reading comprehension. The result of Mann Whitney U test for vocabulary knowledge aspect was tabulated in Table 4 below.

Table 4 summarized the results obtained of Mann Whitney U Test on vocabulary knowledge of the survey. The results showed that most of the learners had a dictionary and they often use dictionary to search for the meaning of the words. However, there was a visible difference regarding their perspectives on the use of dictionary, in which female learners thought that dictionary was beneficial to assist them in the reading process compared to male learners, with mean rank, $\mathrm{MR}=56.69$ and $\mathrm{MR}=44.31$ respectively. For instance, item V5 scored a higher mean rank for female learners $(\mathrm{MR}=56.11)$, compared to male learners $(M R=44.89$. In addition, most of the female learners $(M R=$ 59.40) knew how to use the dictionary to find the meaning of words compared to male learners $(\mathrm{MR}=41.60)$. From this, it could be concluded that the female learners used dictionary as a source or tool to expand their vocabulary knowledge compared to male learners. In contrast, male learners use dictionary more

Table 4. Mann whitney U Test on vocabulary knowledge between genders.

\begin{tabular}{|c|c|c|c|c|}
\hline & Gender & $\mathbf{N}$ & Mean Rank & Sum of Ranks \\
\hline \multirow{3}{*}{ Have a dictionary $\left(V_{-} \_1\right)$} & Male & 50 & 49.00 & 2450.00 \\
\hline & Female & 50 & 52.00 & 2600.00 \\
\hline & Total & 100 & & \\
\hline \multirow{3}{*}{ Often use dictionary $\left(\mathrm{V} \_2\right)$} & Male & 50 & 55.02 & 2751.00 \\
\hline & Female & 50 & 45.98 & 2299.00 \\
\hline & Total & 100 & & \\
\hline \multirow{3}{*}{$\begin{array}{l}\text { Know how to use a dictionary to } \\
\text { search the meaning of words } \\
\text { (V_3 })\end{array}$} & Male & 50 & 41.60 & 2080.00 \\
\hline & Female & 50 & 59.40 & 2970.00 \\
\hline & Total & 100 & & \\
\hline \multirow{3}{*}{$\begin{array}{l}\text { Dictionary helps a lot as a } \\
\text { source of reference to learn and } \\
\text { understand unfamiliar words } \\
\text { (V_4) }\end{array}$} & Male & 50 & 44.31 & 2215.50 \\
\hline & Female & 50 & 56.69 & 2834.50 \\
\hline & Total & 100 & & \\
\hline \multirow{3}{*}{$\begin{array}{l}\text { Dictionary is a helpful tool in } \\
\text { learning process }\left(V_{-} 5\right)\end{array}$} & Male & 50 & 44.89 & 2244.50 \\
\hline & Female & 50 & 56.11 & 2805.50 \\
\hline & Total & 100 & & \\
\hline
\end{tabular}


often ( $M R=55.02)$ compared to female learners $(M R=45.98)$. This showed that male learners relied heavily on dictionary to search for meaning of unfamiliar words. Axiomatically, all items from V_1 to V_5 indicated no significant difference between male and female learners $(p>0.05)$. Hence, there was no significant different between male and female learners with respect to their vocabulary knowledge.

\subsection{Discussion}

\subsubsection{The Factors Affecting Reading Comprehension among Level 2 Primary School ESL Learners}

\section{1) Motivation}

Motivation was one of the crucial factors which impacted greatly on language learning, specifically in reading comprehension. In this study, lack of motivation and interest to read had been identified as a key factor that impeded the mastery of reading comprehension skill among level 2 primary school ESL learners in Mukah, Sarawak. Grabe \& Stoller (2002) agreed that reading motivation was significant for ESL learners and it helped to increase learners' reading comprehension. It was a drive for the learners to continue reading and understand the text effectively. This is because motivation and interest in reading was the enormous quantity of motivation that changed their perspective, either positively or negatively, about reading (Seymour \& Walsh, 2006). For instance, learners who had the habit of reading at least two hours daily were extremely motivated readers. Learners of this kind usually considered reading to be a vital part of their daily activities and they tend to read a wider range and verities of reading materials. This was supported by Schutte \& Malouff (2007) who stated that learners with higher motivation and interest in reading were expected to read a wider range of reading materials in the target language. Moreover, learners' intrinsic motivation was a determiner of the learners' reading amount as reading motivation was directly proportional to the amount of books that they read. Wang \& Guthrie (2004) signified that learners' intrinsic motivation to read a strong indicator of the learners' determination to read and comprehend the text. Ergo, motivation and interest to read related to all features and greatly impacted on reading comprehension and facilitated reading in different levels of learners. Learners with low motivation and lack of interest to read the materials in the target language tend to give up when they encountered more complex and difficult reading text. Moreover, reading motivation is an important variable which led the learners to read more and it had positive relationship with reading and recognizing texts (Morgan \& Fusch, 2007). Henceforth, teachers played an important role to boost learners' reading motivation by allowing them to choose their favourite reading materials to begin with. Schutte \& Malouff (2007) suggested that learners would like to read more if they were given the opportunities to select their own reading materials. Thus, reading motivation and interest is a significant key factor to enhance learners' reading comprehension.

\section{2) Prior Knowledge}


The main purpose of reading in a primary classroom was reading for comprehension. Background knowledge or prior knowledge was one of the variables that had been identified as a key factor that affecting reading comprehension among ESL learners in primary schools in Mukah, Sarawak. Harvey \& Goudvis (2007) emphasized that one of the strategies to enhance reading comprehension was activation of prior knowledge. Prior knowledge acted as scaffolding, in which helped the learners to understand and remember better when they already built on existing information that they already knew. Based on the findings of this research, the learners were having difficulties to relate their background knowledge to the reading text, which later obstruct their understanding while reading a text. Logically, the more a reader knew about a topic, the easier it was to understand what was written about it. In addition, reading was an active engagement between readers and the reading text, whereby the readers would apply various strategies to comprehend and make meaning of the text. This is supported by Brown (2001) who stated that the reader would bring information, knowledge, emotion, and culture that was schemata, to the printed text. Similarly, Cook (1997) believed that schema theory proposed that reading process required the learners to combine their previous knowledge or experience with the text they were reading. When a reader's prior knowledge was activated, he was linking what he already knew to what he was currently reading. This showed that learners' comprehension of a text depended on how much their schema related to the reading text. Consequently, learners' failure to make sense of a text is caused by their insufficient of appropriate schemata that could fit with the content of the reading text. Thus, it was essential for the teachers to plan activities that would activate learners' prior knowledge before reading to help them getting the cues or closest prediction of the context in the reading text. A well prepared learner for reading would have a better comprehension (Yule, 2000). The teacher should guide the learners to bring out learners' background knowledge about a topic so that the learners could assimilate their schema to the information and understand it. Therefore, the activation of learners' prior knowledge was an essential element that aided in reading comprehension. Teachers played a significant role in activating young learners' schema through classroom instructions such as brainstorming, giving context cues and prediction activities so that they could make meaning of the reading text and had a better understanding of it.

\section{3) Vocabulary}

The role of vocabulary in reading comprehension was an intriguing and complex argument. Adams (2004) stressed that in order to construct a mental representation of a reading text, specifically to understand the meaning of the printed text, learners needed to decode the printed message. The findings of this research indicated that most of the learners aged between 10 years old to 12 years old relied heavily on dictionary to search for the meaning of the words during reading. Besides, most of them agreed that dictionary was an important tool that 
helped them to find the meaning of the words. The inability to recognize words in a reading text and the used of high density of unknown words in a text might hinder comprehension (Nation, 2001). This was because the complex process of comprehending text required a high level of word knowledge, or a wide range of vocabulary mastery. In addition, efficient word recognition, word encoding and lexical access were essential for meaning construction (Adams, 2004). Text difficulty usually measured based on the numbers of low frequency words (unfamiliar vocabulary) used throughout the text. Stahl (2003) indicated that readability indexes included vocabulary as a major component, suggesting that word difficulty greatly affected text comprehension. Due to this, learners with lack of vocabulary knowledge would most likely to lost interest and demotivated to continue reading the text. Hence, vocabulary size was a reliable predictor of reading comprehension. Nation (2001) emphasized that vocabulary threshold had significantly contributed to reading comprehension performance in second language learning. Stenberg (1987) claimed that learners' level of vocabulary was highly predictive of their reading comprehension ability. Learners who did not know the meanings of many words were probably poor readers (Anderson \& Freebody, 1983). The finding of this research suggested that vocabulary difficulty impeded reading comprehension performance among the young ESL learners.

\subsubsection{Differences between Males and Females with Respect to the Factors Affecting the Reading Comprehension}

Motivation, either extrinsic or intrinsic, is the main drive for an individual to achieve the goal and accomplishing a task. A few studies on gender differences in motivation and demotivation to learn second language had been conducted. For example, Mori \& Gobel (2006) signifies that female students shows a greater interest in the cultures of people and target language compared to the male students. In England, a study by Williams et al. (2002) indicates that girls express a higher degree of desire and integrative orientation in learning French. These studies explain that male students have less motivation in learning the second language and that contributed to the lesser number of English books read by the male, whereas female pupils read more and acquired higher scores compared to males.

Through previous researches as cited in Bonomo (2017), male pupils are justified to have larger amygdala which causes them to be emotional stimulation and more aggressive. Moreover, they have larger inferior parietal lobe which enable them to be more adapt to symbol and mathematic skill. In term of sensory perception, they are mediated by adrenalin which lead them to be kinesthetic learners. Through these differences, they have different learning preferences. Thus, Elliot \& Klobucar (2013) claimed that lesson should be conducted by taking into account of their learning preference so as to meet their interest. However, in today's classrooms especially language classroom is more girl-friendly, boys can become disengaged, bored and frustrated. Pupils are conceptualized as a bundle of cognitive skills. To maximize the full potential of the male pupils by activating 
their interest, the brain should be utilized holistically. This was in line with the brain theory of Herrmann model as cited in Hughes \& Devine (2015). They claimed that learning requires a balance of the brain's four core skills. Quadrant " $A$ " enabled learners to solve problem with rational thought, while quadrant " $B$ " learns through the technique of organization. On the other hand, the learners who are dominant in quadrant " $C$ " learn through intuitive while quadrant " $D$ " learners prefer creative problem solving such as game playing. Ergo, reading motivation is not differentiated by genders, however there are other contributing factors such as genre preferences, approaches used in the classroom, and pupils' learning preferences.

Apart from that, the findings of this study showed that vocabulary knowledge is one of the determinants that influenced learners' comprehension skill. This is evidenced as the participants agreed that they did not use dictionary as their source of reference. Furthermore, they also did not use dictionary often. Gunning (2006) also stated that vocabulary knowledge is one of the main hindrances in reading comprehension. Baker (1995) suggested that vocabulary knowledge and reading comprehension were interdependent and there was a strong relationship between the two in understanding a reading text. One of the possible reason on low vocabulary knowledge of ESL primary learners was their adverse attitudes towards reading in English as most of them did not include reading as their hobby and only a few participants read at least two hours every day.

\subsection{Limitation}

Nevertheless, the finding of this research should be not generalized to the whole population of Level 2 pupils in Malaysian primary classroom as it is a small-scale research. It could be used as a reference for future studies regarding language learning and development among the young learners. Besides that, the findings of this study were limited to three variables that affecting ESL learners' reading comprehension namely motivation and interest, prior knowledge and vocabulary. A future study could be conducted to determine the other factors and effectively identified some interventions that might help to enhance ESL learners' reading comprehension skill.

Apart from that, the researcher should consider learners' socio-economic backgrounds because the data provide more information on learners' accessibility to English language materials and resources, in which may affect their perspectives and comprehension in English language. As the sample were among 10-year-old to 12-year-old learners, they might need guidance to understand the meaning of the items in the questionnaire. However, the researcher was unable to guide the learners as the instrument was administered via Google Form.

Last but not least was the heterogeneity of the sample. The sample of this study were from low socio-economic backgrounds and living in a sub urban area which allow generalization of the results only to other similar samples. Additionally, the learners were chosen to participate in this study due to researcher's 
reachability to the participants, not solely on their reading comprehension ability. Henceforth, purposive sampling can be used to generate a more reliable data of reading comprehension ability.

\section{Conclusion}

Reading comprehension is a foundation in the success of learning a language since it has a profound effect on the other language skills. It helps the learners to develop the concept of knowledge in order to become a successful and competent readers as well as language users. However, the stereotypes mindset, which indicates that males' learners are not interested in reading should be changed. Perhaps, approaches and the choices of genres should be carefully taken into account to inculcate the reading habit among the learners. For future study, it is suggested that purposive sampling is used to select the samples with reading difficulties so that the result will be more reliable. Apart from that, further research on motivation and learning strategies between genders can be conducted in order to examine the differences between male and female learners. Learning styles and preferences should be taken into account so that reading difficulties among ESL learners can be effectively overcome.

\section{Conflicts of Interest}

The authors declare no conflicts of interest regarding the publication of this paper.

\section{References}

Adams, M. J. (2004). Theoretical Model and Processes of Reading. Newark, DE: International Reading Association.

Ahmadi, M. R., \& Porhossein, G. A. (2012). Reciprocal Teaching Strategies and Their Impacts on English Reading Comprehension. Theories and Practice in language Studies, 2, 2053-2060. https://doi.org/10.4304/tpls.2.10.2053-2060

Alfassi, M. (2004). Reading to Learn: Effects of Combined Strategy Instruction on High School Student. The Journal of Educational Research, 97, 171-185. https://doi.org/10.3200/JOER.97.4.171-185

Anderson, R. C., \& Freebody, P. (1983). Advances in Reading Research. Greenwich, CT: JAI Press.

Baker, S. (1995). Vocabulary Acquisition: Synthesis of the Research. Eugene, OR: National Center to Improve Tools of Educators.

Bernhadt, E. B. (2011). Reading Development in Second Language: Theoretical, Empirical, and Classroom Perspectives. Norwood, NJ: Ablex.

Bonomo, V. (2017). Brain-Based Learning Theory. Journal of Education and Human Development, 6, 27-43. https://doi.org/10.15640/jehd.v6n1a3

Brown, H. D. (2001). Teaching by Principles: An Approach to Language Pedagogy. White Plains, NY: Addison Wesley Longman.

Byram, M. (2011). From Foreign Language Education to Education for Intercultural Citizenship. Language Teaching Research, 22, 1-15.

Cain, K., Oakhill, J., \& Bryant, P. (2004). Children's Reading Comprehension Ability: 
Concurrent Prediction by Working Memory, Verbal Ability, and Component Skills. Journal of Educational Psychology, 96, 31-42. https://doi.org/10.1037/0022-0663.96.1.31

Carrell, P. L., \& Eisterhold, J. J. C. (2012). Schema Theory and ESL Reading Pedagogy. TESOL Quarterly, 17, 553-573. https://doi.org/10.2307/3586613

Carrell, P., \& Wise, E. T. (1998). The Relationship between Prior Knowledge and Topic Interest in Second Language Reading. Studies in Second Language \& Acquisition, 20, 285-309. https://doi.org/10.1017/S0272263198003015

Chang, K. L. et al. (2018). Relooking at the ESL Reading Comprehension Assessment for Malaysian Primary Schools. English Language Teaching, 11, 146.

https://doi.org/10.5539/elt.v11n7p146

Cook, G. (1997). Key Concepts in ELT: Schemas. ELT Journal, 51, 86. https://doi.org/10.1093/elt/51.1.86

CresWell, J. W. (2005). Educational Research: Planning, Conducting and Evaluating Qualitative Research (2nd ed.). Upper Saddle River, NJ: Pearson Education.

David, C. (2003). English as a Global Language (2nd ed.). Cambridge: Cambridge University Press.

Denton, C., \& Otoiba, S. (2011). Teaching Word Identification to Students with Reading Difficulties and Disabilities. Focus on Exceptional Children, 43, 1-16. https://doi.org/10.17161/foec.v43i7.6911

Elliot, N., \& Klobucar, A. (2013). Automated Essay Evaluation and the Teaching of Writing. In M. D. Shermis, \& J. Burstein (Eds.), Handbook of Automated Essay Scoring (pp. 16-35). New York and London: Routledge.

Eun, K. Y. (2015). Promoting L2 Vocabulary Learning through Narrow Reading. RELC Journal, 46, 165-179.

Floyd, P., \& Carrell, P. (1987). Effects on ESL Reading of Teaching Cultural Content Schemata. Language Learning, 37, 89-108. https://doi.org/10.1111/j.1467-1770.1968.tb01313.x

Fong, P. C. (2012). Literacy among the Secondary Students in Malaysia. International Journal of Social Science and Humanity, 2, 34-45.

Golden, S. E., \& Wilson, N. S. (2015). Reading Engagement: A Comparison between E-Books and Traditional Print Books in an Elementary Classroom. https://members.aect.org/pdf/Proceedings/proceedings10/2010/10_17.pdf

Grabe, W., \& Stroller, L. F. (2002). Teaching and Researching Reading. London: Pearson Education Longman.

Gunning, T. G. (2006). Assessing and Correcting Reading and Writing Difficulties. Boston, MA: Pearson.

Guthrie, J. T., \& Wigfield, A. (2000). Engagement and Motivation in Reading. In M. L. Kamil, P. B. Mosenthal, P. D. Pearson, \& R. Barr (Eds.), Handbook of Reading Research (Vol. 3, pp. 403-422). New York: Erlbaum.

Guthrie, J. T., Coddington, C. S., \& Wigfield, A. (2009). Profiles of Reading Motivation among African American and Caucasian Students. Journal of Literacy Research, 41, 317-353. https://doi.org/10.1080/10862960903129196

Hanlon, B., \& Larget, B. (2011). Samples and Population. http://pages.stat.wisc.edu/ st571-1/03-samples-4.pdf

Harvey, S., \& Goudvis, A. (2007). Strategies That Work: Teaching Comprehension for Understanding and Engagement (2nd ed.). Portland, ME: Stenhouse Publishers. 
Hassan, M. A. (2004). Research Population.

https://www.academia.edu/5563491/Research_Population

Hellekjaer, G. O. (2009). Academic English Reading Proficiency at the University Level: A Norwegian Case Study. Reading in Foreign Language, 21, 198-222. https://doi.org/10.5617/adno.1022

Huey, E. B. (1908). The Psychology and Pedagogy of Reading (5th ed.). Cambridge, MA: MIT Press. https://doi.org/10.2307/2011165

Hughes, C., \& Devine, R.T. (2015). A Social Perspective on Theory of Mind. In M. E. Lamb (Ed.), Handbook of Child Psychology and Developmental Science (Vol. 3). Hoboken, NJ: Wiley. https://doi.org/10.1002/9781118963418.childpsy314

Iqbal, M., Noor, M., Muhabat, F., \& Kazemian, B. (2015). Factors Responsible for Poor English Reading Comprehension at Secondary Level. Communication and Linguistic Studies, 1, 1-6. https://doi.org/10.2139/ssrn.2602630

Jun, L. Z., \& Wu, A. (2009). Chinese Senior High School EFL Students' Metacognition Awareness and Reading Strategy Use. Reading in a Foreign Language, 21, 37-59.

Kamarundzaman, N. S. (2014). Using Phonics System to Develop Pupils Reading Proficiency. Skudai: Universiti teknologi Malaysia.

Kintsch, W., \& Kintsch, E. (2005). Comprehension. In S. G. Paris, \& S. A. Stahl (Eds.), Children's Reading Comprehension and Assessment (pp. 71-92). Mahwah, NJ: Ablex.

Koda, K. (2007). Phonemic Awareness and Reading Comprehension among Japanese Adult Learners of English. Open Journal of Modern Linguistics, 4, 471-480.

Krashen, S., \& Brown, C. L. (2007). What Is Academic Language Proficiency? STETS Language and Communication Review, 6, 1-4.

Kruger, L. (2008). The Relationship between Reading Fluency and Comprehension in Spanish Language Measures. ProQuest Digital Dissertations Database (Publication No. 3339311).

Laufer, B. (1989). What Percentage of Text Lexis Is Essential for Comprehension? In C. Lauren, \& M. Nordman (Eds.), Special Language: From Humans Thinking to Thinking Machines (pp. 316-323). Clevedon: Multilingual Matters.

Liu, L. C., Maarof, N., \& Yunus, M. Md. (2016). Factors Affecting ESL Reading Comprehension of Malaysian Secondary School Students. International Conference on Education, Indonesia, 22 November 2016, 542-547.

Malaysia Educational Statistics (2018). Quick Facts 2018-2017. https://www.moe.gov.my/penerbitan/1587-quick-facts-2018-malaysia-educational-stati stics-1/file

Mansor, N. (2017). Exploring Perceptions on ESL Students Reading Habits. Journal of Business and Social Development, 5, 19-24.

Morgan, R., \& Fuchs, D. (2007). Is There a Bidirectional Relationship between Children's Reading Skill and Reading Motivation? Exceptional Children, 73, 165-183. https://doi.org/10.1177/001440290707300203

Mori, S., \& Gobel, P. (2006). Gender, Motivation, and Attendance among University Students. Proceedings of JALT 2004, Tokyo, 22 May 2004, 290-302.

Nation, I. S. (2001). Learning Vocabulary in Another Language. Cambridge: Cambridge University Press. https://doi.org/10.1017/CBO9781139524759

Nation, I. S. (2011). Learning Vocabulary in Another Language. Cambridge: Cambridge University Press.

Nguyen, T. T. (2007). The Impact of Background Knowledge and Time Constraint on 
Reading Comprehension of Vietnamese Learners of English as a Second Language. Theses, Carbondale, IL: Southern Illinois University Carbondale.

Panigrahi, S. S. (2010). Teaching of English. New Delhi: A.P.H Publishing Corporation.

Pasquarella, A. D. K. (2009). Reading Comprehension in Adolescent First and Second Language. Waterloo: Wilfrid Laurier University.

Paynter, D. E., Bodrova, E., \& Doty, J. K. (2009). For the Love of Words: Vocabulary Instructions that Works. San-Francisco, CA: Jersey-Bass.

Pearson, D., \& Anderson, R. C. (1985). Reading Comprehension: What Works. Educational Leadership, 51, 2-7.

Phantharakphong, P., \& Pothitha, S. (2014). Development of English Reading Comprehension by Using Concept Maps. Procedia-Social and Behavioural Sciences, 116, $497-$ 501. https://doi.org/10.1016/j.sbspro.2014.01.247

Pollard, A., Black-Hawkins, K., Hodges, G. C., Dudley, P., James, M., Swaffield, S., Linklater, H., Swann, M., Turner, F., Warwick, P., Winterbottom, M., \& Wolpert, A. M. (2014). Reflective Teaching in Schools. London: Bloomsbury.

Randi, J., Newman, T., \& Grigorenko, E. L. (2010). Teaching Children with Autism to Read for Meaning: Challenges and Possibilities. Journal of Autism and Developmental Disorders, 40, 890-902. https://doi.org/10.1007/s10803-010-0938-6

Rashid, A. M. (2012). Teachers' Understanding and Practice towards Thematic Approach in Teaching Integrated Living Skills (ILS) in Malaysia. International Journal of Humanities and Social Science, 2, 472.

Reddy, M. S., \& Mahavidyalaya, P. (2016). Importance of English Language in Today's World. International Journal of Academic Research, 3, 179-184.

Sadiku, L. M. (2015). The Importance of Four Skills Reading, Speaking, Writing, Listening in a Lesson Hour. European Journal of Language and Literature, 1, 29-31. https://doi.org/10.26417/ejls.v1i1.p29-31

Schutte, N. S., \& Malouff, J. M. (2007). Dimensions of Reading Motivation: Development of an Adult Reading Motivation Scale. Reading Psychology, 28, 469-489. https://doi.org/10.1080/02702710701568991

Scott, J. A. (2010). Essential, Enjoyable and Effective: The What, Why and How of Powerful Vocabulary Instruction. Literacy Learning: The Middle Years, 23, 14-23.

Seymour, S., \& Walsh, L. (2006). Essentials of Teaching Academic Reading. Boston, MA: Houghton Mifflin Harcourt.

Shankweiler, D., Lundquist, E., Katz, L., Stuebig, K. K., Fletcher, J. M., Brady, S., \& Shaywitz, B. A. (1999). Comprehension and Decoding: Patterns of Association in Children with Reading Difficulties. Scientific Studies of Reading, 3, 69-94.

https://doi.org/10.1207/s1532799xssr0301_4

Solheim, O. J. (2011). The Impact of Reading Self-Efficacy and Task Value on Reading Comprehension Scores in Different Item Formats. Reading Psychology, 32, 1-27. https://doi.org/10.1080/02702710903256601

Stahl, S. A. (2003). Vocabulary and Readability: How Knowing Word Meanings Affects Comprehension. Topics in Language Disorders, 23, 241-247. https://doi.org/10.1097/00011363-200307000-00009

Stanovich, K. E. (1986). Matthew Effects in Reading: Some Consequences of Individual Differences in the Acquisition of Literacy. Reading Research Quarterly, 2, 360-407. https://doi.org/10.1598/RRQ.21.4.1

Stenberg, R. J. (1987). Most Vocabulary Is Learned from Context. In M. G. Mckeown, \& 
M. E. Curtis (Eds.), The Nature of Vocabulary Acquisition (pp. 89-105). Mahwah, NJ: Lawrence Erlbaum Associates, Inc.

Torgeson, J. K. (2006). Reading Fluency: Critical Issues for Struggling Readers. In S. J. Samuel, \& A. E. Farstrup (Eds.), What Research Has to Say about Fluency Instruction (pp. 130-158). Washington DC: International Reading Association.

Vacca, R. T., \& Vacca, L. J. A. (2008). Content Area Reading: Literacy and Learning across the Curriculum. Boston, MA: Allyn \& Bacon.

Vazalwar, C. H. (2011). Effect of Anxiety on Reading Comprehension in English. International Journal of Multidisciplinary Research, 1, 272-278.

Vellutino, F. R. et al. (2004). Specific Reading Disability (Dyslexia): What Have We Learned in the Past Four Decades? Journal of Child Psychology and Psychiatry, 45, 2-40. https://doi.org/10.1046/j.0021-9630.2003.00305.x

Walcutt, C. C. (1967). Reading-A Professional Definition. The Elementary School Journal, 67, 363-365. https://doi.org/10.1086/460385

Walker, V. L. (2001). Traditional versus New Media: Storytelling as Pedagogy for African American Children. Austin, TX: The University of Texas.

Wang, J. H., \& Guthrie, J. T. (2004). Modeling the Effects of Intrinsic Motivation, Extrinsic Motivation, Amount of Reading, and Past Reading Achievement on Text Comprehension between U.S and Chinese Students. Reading Research Quarterly, 39, 162-186.

https://doi.org/10.1598/RRQ.39.2.2

Williams, D., Consalvo, M., Caplan, S., \& Yee, N. (2002). Looking for Gender Roles and Behaviors among Online Gamers. Journal of Communication, 59, 700-725. https://doi.org/10.1111/j.1460-2466.2009.01453.x

Wolf, M., \& Bowers, P. G. (1999). The Double-Deficit Hypothesis for the Dyslexia. Journal of Educational Psychology, 91, 415-438. https://doi.org/10.1037/0022-0663.91.3.415

World Population Review (2019). English Speaking Countries 2019. https://worldpopulationreview.com/country-rankings/english-speaking-countries

Yule, G. (2000). Pragmatics. Oxford: Oxford University Press.

Yunus, K., Mohamad, M., \& Waelateh, B. (2016). The Breadth of Receptive Vocabulary Knowledge among English Major University Students. Journal of Nusantara Studies (JONUS), 1, 7-17. https://doi.org/10.24200/jonus.volliss1pp7-17

Zare, P., \& Nooreen, N. (2011). The Relationship between Language Learning Strategy Use and Reading Comprehension Achievement among Iranian Undergraduate EFL Learners. World Applied Sciences Journal, 13, 1870-1877. 